DOI: 10.46340/eujem.2021.7.1.20

Andrii Halaiko

ORCID ID: https://orcid.org/0000-0002-0569-3032

Ivan Franko National University of Lviv, Ukraine

\title{
THE ANALYSIS OF THE INFLUENCE \\ OF VALUE ADDED TAX ON FINANCIAL INDICATORS OF THE ACTIVITY OF AGRO-INDUSTRIAL COMPLEX IN UKRAINE
}

\author{
Андрій Галайко \\ Львівський національний університет імені Івана Франка, Україна

\section{АНАЛІЗ ВПЛИВУ ПОДАТКУ НА ДОДАНУ ВАРТІСТЬ НА ФІНАНСОВІ ПОКАЗНИКИ ДІЯЛЬНОСТІ АГРОПРОМИСЛОВОГО КОМПЛЕКСУ В УКРАЇНІ}

This article focuses on the determination of the influence of value added tax and of gross capital investment on such financial indicators of the activity of agro-industrial economic entities as the size of the producing and the realization of products, financial results before taxation, net profit, payment of value added tax and of income tax to the State Budget of Ukraine. As a result of the research, it is established that decreasing of value added tax would increase significantly the sizes of the activity of agro-industrial complex. Herewith the increasing of payment to the State Budget of Ukraine of value added tax and of income tax happens with insignificant measure because of the expansion of the amounts of agro-industrial activity. It is related with whereby, that part of agricultural enterprises uses simplified system of taxation at which income tax is not paid to state budget, and other part of agricultural producers used special regime of taxation with value added tax to 2017, wherein this tax payment was not paid to the State Budget of Ukraine. The state can cover expenses and get revenues in the case, when the size of the decreasing of value added tax will be amounting no more $16,67 \%$ of gross capital investment. It is found out that direct and converse connection was existing between value added tax and amount of produce. When the sizes of the work of agro-industrial complex will be increasing, and because of this payment to state budget will be increasing, value added tax then will be in the direct connection. If state will be altering the rate of this tax payment and in result of this will be altering the amount of the producing of the products of agro-industrial economic entities, then in that case converse connection will exist. In future, this research can be conducted taking into account next periods of the activity of agro-industrial complex.

Key words: value added tax, gross capital investment, financial resources, agro-industrial complex, state funds, financial indicators.

Постановка проблеми. Податкова підтримка агропромислових компаній відіграє ключову роль в їх розвитку, тому що вони функціонують в такій галузі економіки України, яка забезпечує населення продуктами харчування і продовольчу безпеку держави. Відповідно до цього, актуальним питанням постає розрахунок впливу податку на додану вартість на діяльність агропромислового комплексу з подальшим аналізом ефективності такого видку державної підтримки. Це дасть змогу проводити податкове стимулювання розвитку даної галузі економіки на визначеному рівні. В даній роботі буде зроблено акцент на створенні системи розрахунків за кореляційно-регресійним аналізом, які будуть характеризувати зміну таких фінансових показників діяльності агропромислових підприємств, як-от: розмір виробництва і продажу продукції, фінансові результати до оподаткування, чистий прибуток, сплата до Державного бюджету України податку на додану вартість і податку на прибуток внаслідок зміни податку на додану вартість та валових капітальних інвестицій. 
Аналіз останніх досліджень та публікацій. Проблемам податкової підтримки розвитку підприємств в аграрному секторі економіки в економічній літературі зазвичай приділяється велика увага. Доцільно виділити наукові праці автора А. М. Галайка, який досліджував вплив пільг з податку на прибуток на фінансові показники діяльності агропромислових фірм; напрями покриття видатків на податкове стимулювання розвитку даної галузі економіки шляхом надання пільг з податку на прибуток; вплив бюджетної підтримки агропромислового комплексу на роботу його господарюючих суб'єктів; напрями відшкодування видатків держави на бюджетне фінансування агропромислових компаній; ефективність використання валових капітальних інвестицій в агропромисловій сфері економіки України. Науковець Н. С. Шалімова проводила оцінювання розмірів бюджетного фінансування сільськогосподарських виробників з врахуванням пріоритетів регіонального розвитку в процесі її одержання. Державна служба статистики України кожного року опубліковує результати діяльності підприємницьких структур за видами економічної діяльності, включаючи сільське, лісове і рибне господарство. Вони охоплюють розмір виробництва і продажу продукції, фінансові результати до оподаткування, чистий прибуток, валові капітальні інвестиції. Незважаючи на численні дослідження в цій галузі, існує необхідність розрахунку впливу податку на додану вартість на такі показники діяльності агропромислових компаній, як-от: розмір виробництва і продажу продукції, фінансові результати до оподаткування, чистий прибуток, сплата до Державного бюджету України податку на додану вартість і податку на прибуток. Також існує потреба встановити співвідношення між обсягом зменшення податку на додану вартість і розміром валових капітальних інвестицій, яке дасть можливість державі повернути видатки на податкову підтримку та отримати додаткові доходи.

Мета цієї статті $\epsilon$ проведення аналізу впливу податку на додану вартість на фінансові показники діяльності підприємств агропромислового комплексу та встановлення напрямів покриття видатків держави на податкове стимулювання розвитку даної галузі економіки.

Виклад основного матеріалу. Державна підтримка агропромислового комплексу передбачає фінансування з Державного бюджету України його суб'єктів господарювання, цінове регулювання, податкову підтримку, а також інші заходи непрямого впливу, які суттєво впливають на ефективну роботу даної галузі економіки України ${ }^{1}$. Пряма державна підтримка проводиться через надання бюджетних асигнувань і бюджетних позик. Надання податкових пільг є непрямим видом державної підтримки агропромислового виробництва в Україні².

Аналіз ефективності податкової підтримки розвитку підприємств в агропромисловому комплексі здійснюватиметься шляхом розрахунку впливу податку на додану вартість на такі фінансові показники їх діяльності, як-от: обсяг виробництва продукції, розмір ії реалізації з податком на додану вартість і без даного податкового платежу, фінансові результати до оподаткування, чистий прибуток, сплата до Державного бюджету України податку на додану вартість та податку на прибуток. На основі таких розрахунків буде встановлено розмір фінансових ресурсів, котрі держава матиме можливість повернути шляхом сплати податку на прибуток і податку на додану вартість. В процесі даного аналізу не буде братися до уваги бюджетне відшкодування податку на додану вартість, яким являється компенсація державою обсягу цього податкового платежу, котрий був сплачений у вартості куплених товарів, робіт і послуг.

У таблиці 1 наведено обсяг виробництва і продажу продукції агропромислового комплексу, валові капітальні інвестиції а також індекс інфляції.

\footnotetext{
${ }^{1}$ Електронне сховище Уманського національного університету садівництва (2020). Методичні підходи до визначення рівня державної підтримки аграрного сектору <http://lib.udau.edu.ua/bitstream/123456789/4629/1/ Методичні\%20підходи\%20до\%20визначення\%20рівня\%20державної\%20підтримки\%20аграрного\%20сектору.pdf> (2020, листопад, 22).

${ }^{2}$ Шалімова, Н. С. (2017). Оцінка обсягів державної підтримки сільськогосподарських товаровиробників та урахування пріоритетів регіонального розвитку при ії отриманні. Scientific Journal «ScienceRise», 5/2 (34), 12-17. <http://journals.uran.ua/sciencerise/article/view/102514/98192> (2020, листопад, 24).
} 
Таблиця 1

Фінансові показники діяльності агропромислових компаній та індекс інфляції

\begin{tabular}{|c|c|c|c|c|c|c|c|}
\hline Роки & $\begin{array}{c}\text { Валові } \\
\text { капітальні } \\
\text { інвестції } \\
\text { (млн. грн.) }\end{array}$ & $\begin{array}{c}\text { Обсяг } \\
\text { виробництва } \\
\text { продукції } \\
\text { (млн. грн.) }\end{array}$ & $\begin{array}{c}\text { Розмір } \\
\text { реалізованої } \\
\text { подукції з податком } \\
\text { (млнану вартість }\end{array}$ & $\begin{array}{c}\text { Обсяг проданої } \\
\text { продукції } \\
\text { без податку } \\
\text { надану вартість } \\
\text { (млн. грн.) }\end{array}$ & $\begin{array}{c}\text { Податок } \\
\text { на додану } \\
\text { вартість } \\
\text { (млн. грн.) }\end{array}$ & $\begin{array}{c}\text { Індекс } \\
\text { інфляції }\end{array}$ & $\begin{array}{c}\text { Iндекс інфляції } \\
\text { наростаючим } \\
\text { підсумком }\end{array}$ \\
\hline 2005 & 6406,9 & 95520 & 39957,9 & 39387,9 & 570,0 & 1,103 & 1,103 \\
\hline 2006 & 7148,8 & 99154 & 38144,6 & 37287,4 & 857,2 & 1,116 & 1,231 \\
\hline 2007 & 10212,1 & 114031 & 51806,2 & 50812,4 & 993,8 & 1,166 & 1,435 \\
\hline 2008 & 15734,9 & 157208 & 71190,3 & 69634,5 & 1555,8 & 1,223 & 1,755 \\
\hline 2009 & 10186,5 & 159187 & 79618,2 & 78295,8 & 1322,4 & 1,123 & 1,971 \\
\hline 2010 & 11352 & 189373 & 101301,0 & 99891,4 & 1409,6 & 1,091 & 2,151 \\
\hline 2011 & 16892,2 & 253485 & 128257,7 & 126961,2 & 1296,5 & 1,046 & 2,250 \\
\hline 2012 & 19205,8 & 261707 & 164495,9 & 162611,1 & 1884,8 & 0,998 & 2,245 \\
\hline 2013 & 18919,1 & 306998 & 161792,1 & 161130,3 & 661,8 & 1,005 & 2,256 \\
\hline 2014 & 18582,4 & 381227 & 214574,4 & 213929,8 & 644,6 & 1,249 & 2,818 \\
\hline 2015 & 29798,5 & 558788 & 363509,0 & 362310 & 1199,0 & 1,433 & 4,038 \\
\hline 2016 & 50319,6 & 655569 & 411477,4 & 403645,8 & 7831,6 & 1,124 & 4,539 \\
\hline 2017 & 64084,1 & 727352 & 472280,1 & 454380,1 & 17900,0 & 1,137 & 5,161 \\
\hline 2018 & 66576,3 & 871971 & 542096,9 & 525096,9 & 17000 & 1,098 & 5,667 \\
\hline
\end{tabular}

Джерело: складено автором на основі даних ${ }^{1}$

Динаміка вартісної оцінки масштабів діяльності агропромислових господарюючих суб'єктів частково залежить від інфляції. Для того, щоб в подальшому аналізі виключити вплив інфляційних процесів необхідно відкоригувати дані на індекс інфляції з наростаючим підсумком. У таблиці 2 представлено відкориговані фінансові показники діяльності (обсяг виробництва і реалізації продукції, фінансові результати до оподаткування, чистий прибуток, податок на додану вартість) агропромислового сектору економіки України, які скореговані на індекс інфляції з наростаючим підсумком.

Для визначення впливу податку на додану вартість на фінансові показники діяльності агропромислових фірм буде побудовано лінійну кореляційно-регресійну модель, у котрій результуючою ознакою виступатиме розмір виробництва агропромислової продукції, а факторними ознаками - податок на додану вартість і обсяг проданої продукції без цього податкового платежу. У таблиці 3 представлено результати кореляційно-регресійного аналізу впливу податку на додану вартість і розміру реалізованої продукції на обсяг виробництва в агропромисловому комплексі.

\footnotetext{
${ }^{1}$ Державна служба статистики України (2020). Виробництво та розподіл валового внутрішнього продукту за видами економічної діяльності за 2001-2013 <http://ukrstat.gov.ua/operativ/operativ2008/vvp/vvp_ric/vtr_kr_u.htm> (2020, листопад, 16); Галайко, А. М. (2019). Оцінка впливу бюджетної підтримки агропромислового комплексу на фінансові показники діяльності його суб’єктів господарювання. Економіка та держава, 9, 115-122. $<$ http://www.economy.in.ua/?op=1\&z=4408\&i=18> (2020, листопад, 25); Галайко, А. М. (2019). Оцінка впливу валових капітальних інвестицій в агропромисловому комплексі на обсяг виробництва його суб'єктів підприємництва. Сучасні підходи до ефективного використання потенціалу економіки: збірник матеріалів ІІІ Міжнародної науково-практичної конферениії (м. Запоріжж, 19 жовтня 2019 р.), 9-11; Мінфін (2020). Індекс інфляції в Україні <https://index.minfin.com.ua/ua/economy/index/inflation/> (2020, листопад, 16); Кузнєцова, М. (2019). Діяльність суб' єктів господарювання. Статистичний збірник, 163 <http://www.ukrstat.gov.ua/druk/publicat/ Arhiv_u/09/Arch_dsg_bl.htm> (2020, листопад, 14); Agropolit.com (2019). Структура сплачених податків агросектором за 2017-2018 роки: за видами та сферами діяльності <https://agropolit.com/infographics/view/91> (2020, листопад, 18).
} 
Таблиця 2

Скореговані на індекс інфляції 3 наростаючим підсумком обсяг виробництва і продажу продукції, валові капітальні інвестиції і податок на додану вартість в агропромисловому комплексі

\begin{tabular}{|c|c|c|c|c|c|}
\hline Роки & $\begin{array}{c}\text { Валові } \\
\text { капітальні } \\
\text { інвестції } \\
\text { (млн. грн.) }\end{array}$ & $\begin{array}{c}\text { Обсяг } \\
\text { виробництва } \\
\text { прдукії (млн. } \\
\text { грн.) }\end{array}$ & $\begin{array}{c}\text { Розмір реалізованої } \\
\text { продукції з податком } \\
\text { на додану вартість } \\
\text { (млн. грн.) }\end{array}$ & $\begin{array}{c}\text { Обсяг проданої } \\
\text { продукції без податку } \\
\text { надану вартість (млн. } \\
\text { грн.) }\end{array}$ & $\begin{array}{c}\text { Податок на додану } \\
\text { вартість (млн. } \\
\text { грн.) }\end{array}$ \\
\hline 2005 & 5808,6 & 86600,2 & 36226,6 & 35709,8 & 516,8 \\
\hline 2006 & 5807,6 & 80550,9 & 30988,0 & 30291,6 & 696,4 \\
\hline 2007 & 7115,0 & 79448,3 & 36094,7 & 35402,3 & 692,4 \\
\hline 2008 & 8963,9 & 89559,1 & 40556,1 & 39669,8 & 886,3 \\
\hline 2009 & 5167,5 & 80753,8 & 40389,4 & 39718,6 & 670,8 \\
\hline 2010 & 5278,4 & 88053,9 & 47102,5 & 46447,1 & 655,4 \\
\hline 2011 & 7509,1 & 112681,2 & 57014,2 & 56437,8 & 576,4 \\
\hline 2012 & 8554,6 & 116569,2 & 73269,6 & 72430,0 & 839,5 \\
\hline 2013 & 8385,0 & 136062,4 & 71706,7 & 71413,4 & 293,3 \\
\hline 2014 & 6593,9 & 135276,9 & 76140,9 & 75912,2 & 228,7 \\
\hline 2015 & 7378,8 & 138369,7 & 90013,8 & 89716,9 & 296,9 \\
\hline 2016 & 11085,7 & 144426,2 & 90651,2 & 88925,8 & 1725,4 \\
\hline 2017 & 12417,0 & 140932,7 & 91509,6 & 88041,3 & 3468,3 \\
\hline 2018 & 11748,1 & 153868,2 & 95658,5 & 92658,7 & 2999,8 \\
\hline
\end{tabular}

Джерело: складено автором на основі власних розрахунків

Таблиця 3

\section{Результати кореляційно-регресійного аналізу}

\begin{tabular}{|c|c|c|c|c|c|c|}
\hline Множинний R & 0,9748 & & & & & \\
\hline $\mathrm{R}$ - квадрат & 0,9503 & & & & & \\
\hline $\begin{array}{l}\text { Нормований R - } \\
\text { квадрат }\end{array}$ & 0,9413 & & & & & \\
\hline $\begin{array}{l}\text { Стандартна } \\
\text { помилка }\end{array}$ & 6790,6 & & & & & \\
\hline Спостереження & 14 & & & & & \\
\hline \multicolumn{7}{|c|}{ Дисперсійний аналіз } \\
\hline & $d f$ & $S S$ & $M S$ & $F$ & Значення $F$ & \\
\hline Регресія & 2 & 9702888976 & 4851444488 & 105,2 & 0,0000001 & \\
\hline Залишок & 11 & 507230361,3 & 46111851 & & & \\
\hline Всього & 13 & 10210119337 & & & & \\
\hline \multicolumn{7}{|c|}{ Оцінка параметрів рівняння регресії } \\
\hline & Коефіицієнти & $\begin{array}{l}\text { Стандарт } \\
\text { на помилка }\end{array}$ & t-статистика & Р-значення & Нижнс 95,0\% & $\begin{array}{c}\text { Верхне } \\
95,0 \%\end{array}$ \\
\hline Y-перетин & 41301,96 & 5302,343 & 7,789 & 0,00001 & 29631,6 & 52972,3 \\
\hline Змінна $\mathrm{X}_{1}$ & $-0,377$ & 2,180 & $-0,173$ & 0,866 & $-5,174$ & 4,420 \\
\hline Змінна $\mathrm{X}_{2}$ & 1,171 & 0,093 & 12,597 & 0,0000001 & 0,967 & 1,376 \\
\hline
\end{tabular}

Джерело: складено автором на основі власних розрахунків 
Адекватність моделі буде визначено за F-критерієм Фішера. Для цього будуть встановлені ступені вільності $d f_{l}=2, d f_{2}=11$. Критичне значення F-критерієм Фішера дорівнює 3,98 . Розрахункове значення F-критерієм Фішера дорівнює 105,2, яке є більшим за критичне. Тому дана модель $\epsilon$ адекватна реальній дійсності.

Лінійна кореляційно-регресійна модель, що описує залежність виробництва від податку на додану вартість і від обсягу реалізованої продукції без даного податкового платежу має наступний вигляд:

$$
\mathrm{y}=-0,377 x_{1}+1,171 x_{2}+41301,96
$$

де, у - результуюча ознака обсяг виробництва продукції в агропромисловому комплексі (грн.), $\mathrm{x}_{1-}$ факторна ознака податок на додану вартість (грн.), $\mathrm{x}_{2}$ - факторна ознака розмір реалізованої продукції без податку на додану вартість (грн.).

Проведений аналіз показав, що скорочення податку на додану вартість на 1 грн. зумовлює збільшення розміру виробництва агропромислових підприємств на 0,377 грн., а зростання обсягу проданої продукції без податку на додану вартість на 1 грн. збільшує обсяг виробництва 1,171 грн.

Збільшення валових капітальних інвестицій на 1 грн. спричиняє зростання розміру виробництва агропромислової продукції на 8,681 грн. Підвищення обсягу виготовлення продукції на 1 грн. зумовлює розширення величини ії реалізації з податком на додану вартість на 0,834 грн., а без цього податкового платежу - на 0,817 грн. В разі приросту розміру проданої продукції без податку на додану вартість на 1 грн., фінансові результати до оподаткування збільшаться 0,355 грн, а чистий прибуток - на 0,352 грн. Дослідження проведено з врахуванням 2018 року ${ }^{1}$

При розрахунку обсягу реалізованої продукції з податком на додану вартість не береться до уваги бюджетне відшкодування даного податкового платежу. У таблиці 4 представлено розрахунки впливу податку на додану вартість на фінансові показники діяльності суб'єктів господарювання в агропромисловому комплексі за допомогою надбудови “Solver" MS Excel. В даній таблиці факторна ознака впливає на результативну ознаку в другій колонці і на результуючу ознаку в третій колонці. Ознака в другій колонці ще є факторною і вона впливає на результативну ознаку в третій колонці.

Проведені розрахунки свідчать, що з 1 грн. податку на додану вартість, який потрачений на підтримку агропромислового комплексу держава може повернути 0,006 грн. цього податку від зростання обсягів діяльності в даній галузі економіки, а також матиме змогу повернути 0,001 грн. грошових коштів від зростання податку на прибуток. В підсумку, державний бюджет поверне 0,007 грн. (0,006 грн. + 0,001 грн.) та фактично буде витрачати на податкову підтримку розвитку агропромислових суб’єктів господарювання 0,993 грн. (1 грн. - 0,007 грн.) на 1 грн.

Зниження податку на додану вартість суттєво збільшує розмір виробництва i продажу продукції, фінансові результати до оподаткування і чистий прибуток в агропромисловому комплексі. У свою чергу зростає даний податковий платіж і податок на прибуток внаслідок збільшення обсягів діяльності агропромислових суб'єктів господарювання, але незначною мірою. Це пов'язано з тим, що частина сільськогосподарських підприємств користується спрощеною системою оподаткування, при котрій податок на прибуток не справляється до Державного бюджету України, а інша частина сільгоспвиробників до 2017 року використовувала спеціальний режим оподаткування податком на додану вартість, при якому цей податковий платіж також не сплачувався до Державного бюджету України. Виходячи 3 цього, державна підтримка агропромислового сектору економіки в частині зменшення податку на додану вартість $є$ ефективною тільки з точки зору збільшення масштабів діяльності даної галузі.

Між податком на додану вартість і обсягом виробництва продукції $є$ прямий і обернений зв'язки. Якщо розміри діяльності агропромислових компаній зростатимуть, i вони будуть збільшувати сплату до Державного бюджету України податку на додану вартість, то існуватиме прямий зв'язок. Коли держава буде зменшувати ставку цього податку, то розмір виготовлення продукції збільшуватиметься. У такому разі остерігатиметься обернений зв'язок.

\footnotetext{
${ }^{1}$ Галайко, А. М. (2020). Перспективи отримання державою додаткових доходів в агропромисловому комплексі. Інноватика в сучасній освіті та науці: теорія, методологія, практика: матеріали ІІІ Міжнародного літнього наукового симпозіуму (м. Одеса, 24-25 липня 2020 р.), 54-58.
} 
На рисунку 1 наведено вплив податку на додану вартість і валових капітальних інвестицій на фінансові показники діяльності агропромислового сектору економіки України.

Таблиця 4

\section{Результати розрахунків}

\begin{tabular}{|c|c|c|}
\hline $\begin{array}{c}\text { Факторна } \\
\text { ознака }\end{array}$ & $\begin{array}{l}\text { Одночасно факторна } \\
\text { і результативна ознака }\end{array}$ & Результативна ознака \\
\hline колонка 1 & колонка 2 & колонка 3 \\
\hline \multirow{2}{*}{$\begin{array}{l}\text { 1) Зменшення } \\
\text { ПДВ на } 1 \text { грн. } \\
\text { 2) Зростання } \\
\text { валових } \\
\text { капітальних } \\
\text { інвестицій } \\
\text { на } 6 \text { грн. }\end{array}$} & \multirow[t]{2}{*}{$\begin{array}{l}\text { Збільшення обсягу виробництва } \\
\text { продукції на: } \\
\text { 1) } 0,377 \text { грн.; 2) 52,09 грн. }\end{array}$} & $\begin{array}{l}\text { 3ростання обсягу реалізованої продукції з ПДВ на: } \\
\text { 1) }(0,377 \text { грн. * 0,834 грн.) / } 1 \text { грн. }=0,314 \text { грн.; } \\
\text { 2) }(52,09 \text { грн.* } 0,834 \text { грн.) / } 1 \text { грн. }=43,44 \text { грн. }\end{array}$ \\
\hline & & $\begin{array}{l}\text { 3більшення обсягу реалізованої продукції без ПДВ } \\
\text { на: } \\
\text { 1) }(0,377 \text { грн. * } 0,817 \text { грн. }) / 1 \text { грн. }=0,308 \text { грн.; } \\
\text { 2) }(52,09 \text { грн. * 0,817 грн. }) / 1 \text { грн. }=42,554 \text { грн. }\end{array}$ \\
\hline & \multirow[t]{2}{*}{$\begin{array}{l}\text { Збільшення обсягу проданої } \\
\text { продукції без ПДВ на: } \\
\text { 1) 0,314 грн.; 2) 42,554 грн. }\end{array}$} & $\begin{array}{l}\text { 3ростання фінансових результатів до оподаткування } \\
\text { на: } \\
\text { 1) }(0,308 \text { грн. * } 0,355 \text { грн. }) / 1 \text { грн. }=0,109 \text { грн. } \\
\text { 2) }(42,554 \text { грн. *0,355 грн. }) / 1 \text { грн. }=15,107 \text { грн. }\end{array}$ \\
\hline & & $\begin{array}{l}\text { Зростання чистого прибутку на: } \\
\text { 1) }(0,308 \text { грн. *0,352 грн.) / } 1 \text { грн. }=0,108 \text { грн. } \\
\text { 2) }(42,554 \text { грн. * 0,352 грн.) / } 1 \text { грн. }=14,979 \text { грн. }\end{array}$ \\
\hline & $\begin{array}{l}\text { Зростання фінансових } \\
\text { результатів до оподаткування на: } \\
\text { 1) } 0,109 \text { грн.; 2) } 15,107 \text { грн. } \\
\text { і зростання чистого прибутку на: } \\
\text { 1) } 0,108 \text { грн.; 2) } 14,979 \text { грн. }\end{array}$ & $\begin{array}{l}\text { 3більшення сплати до державного бюджету податку } \\
\text { на прибуток на: } \\
\text { 1) } 0,109 \text { грн. }-0,108 \text { грн. }=0,001 \text { грн. } \\
\text { 2) } 15,107 \text { грн. }-14,979 \text { грн. }=0,128 \text { грн. }\end{array}$ \\
\hline & $\begin{array}{l}\text { 3ростання обсягу реалізованої } \\
\text { продукції з ПДВ на: } \\
\text { 1) 0,314 грн.; 2) 43,44 грн. } \\
\text { та зростання обсягу реалізованої } \\
\text { продукції без ПДВ на: } \\
\text { 1) 0,308 грн; 2) 42,554 грн. }\end{array}$ & $\begin{array}{l}\text { Збільшення сплати до державного бюджету ПДВ на: } \\
\text { 1) } 0,314 \text { грн. }-0,308 \text { грн. }=0,006 \text { грн. } \\
\text { 2) } 43,44 \text { грн. }-42,554 \text { грн. }=0,886 \text { грн. }\end{array}$ \\
\hline
\end{tabular}

Джерело: складено автором на основі власних розрахунків

Податкова підтримка агропромислового виробництва коштує державі значних сум бюджетних коштів. Тому необхідно здійснити пошук додаткових джерел фінансових ресурсів для проведення непрямої державної підтримки в умовах дефіциту Державного бюджету України. Компенсувати державні видатки можна лише у випадку надання податкової підтримки при умові залучення підприємствами в свою діяльність у приватних інвесторах чи у держави певного обсягу капітальних інвестицій. Відповідно до цього, актуальним питання постає розрахунок такого розміру податкової підтримки та інвестиційних ресурсів, щоб покрити державні видатки чи забезпечити доходи від такого стимулювання. Для цього будуть використані розрахунки впливу обсягів виробництва i реалізації агропромислової продукції без податку на додану вартість, на фінансові результати до оподаткування і на чистий прибуток, а також на сплату до Державного бюджету України податку на додану вартість і податку на прибуток.

Збільшення валових капітальних інвестицій на 6 грн. зумовить зростання розміру виробництва продукції агропромислових суб'єктів господарювання на 52,09 грн., розміру реалізованої продукції 3 податком на додану вартість на 43,44 грн., обсягу проданої продукції без податку на додану вартість на 42,554 грн., фінансові результати до оподаткування на 15,107 грн. та чистий прибуток на 14,979 грн. Також справляння до Державного бюджету України податку на додану вартість збільшиться на 0,886 грн., а податку на прибуток на - 0,128 грн. 


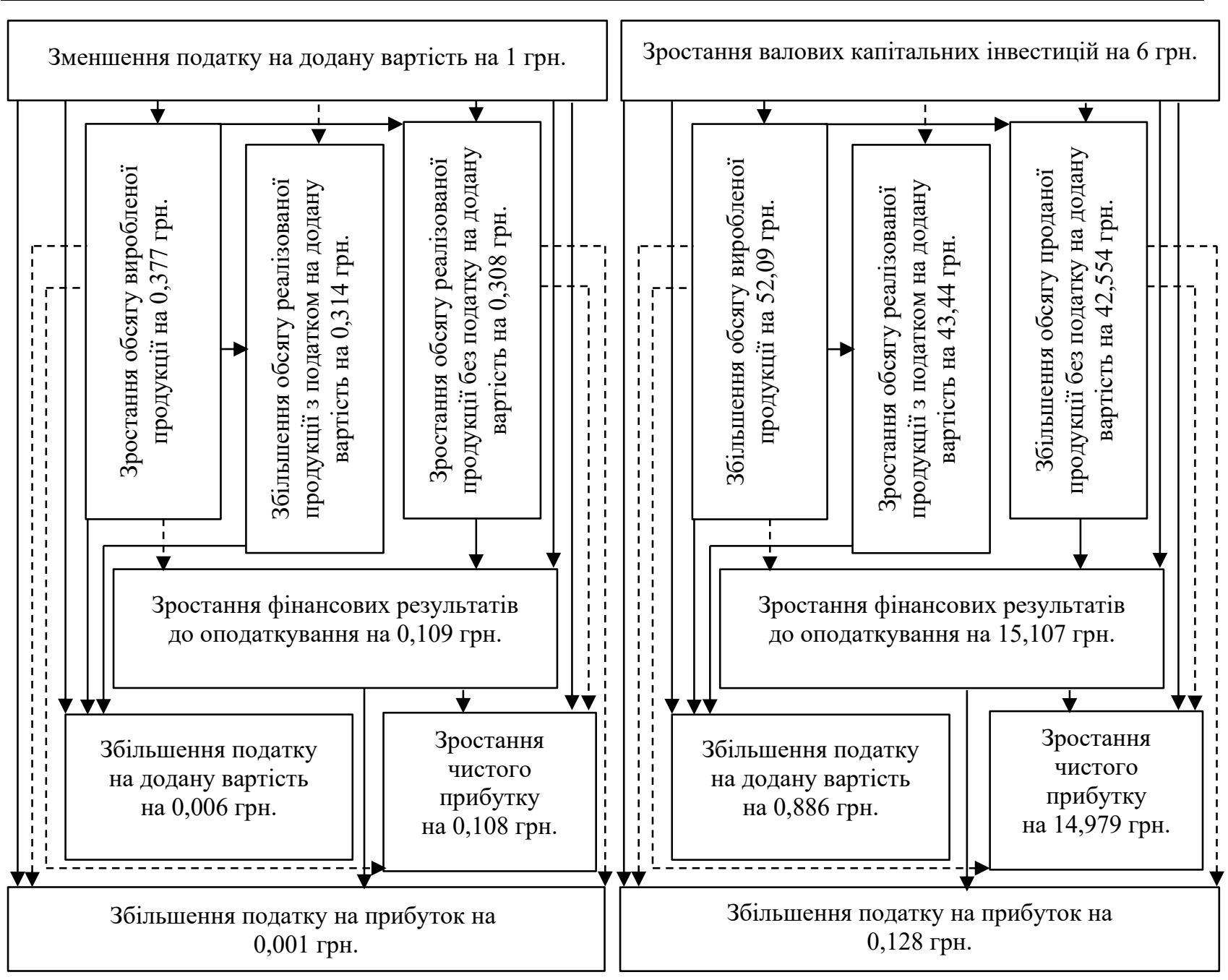

Рис. 1. Вплив податку на додану вартість і валових капітальних інвестицій на фінансові показники діяльності агропромислового комплексу

\section{Джерело: складено автором на основі власних розрахунків}

Якщо держава зумовить зростання валових капітальних інвестицій на 6 грн. і зниження податку на додану вартість на 1 грн., то загальний розмір податкових платежів до бюджету (податку на прибуток і податку на додану вартість) підвищиться на 1,021 грн. $(0,886$ грн. $+0,128$ грн. + $+0,006$ грн. $+0,001$ грн.). Згідно з цим, держава матиме змогу покрити 1 грн., котра була потрачена на податкове стимулювання розвитку агропромислового комплексу і додатково отримати 0,021 грн. доходів. Доходи держава одержуватиме, коли вона збільшить податкову підтримку не вище 1 грн. I валові капітальні інвестиції в агропромисловому секторі економіки зростуть не нижче 6 грн. Це будуть доходи від зростання обсягів роботи агропромислових компаній в результаті збільшення валових капітальних інвестицій, котрі будуть покривати видатки на зростання податкової підтримки та частково покриватимуть загальні видатки на податкове стимулювання розвитку фірм в агропромисловому комплексі. Для повного покриття видатків на непряме державне фінансування агропромислових фірм необхідно досягнути такого стану, щоб розмір податкової підтримки був не вище $16,67 \%$ валових капітальних інвестицій. В інших випадках держава нестиме видатки на податкове стимулювання розвитку виробництва в агропромисловому комплексі. На основі такого підходу є змога формувати такі державні програми податкової підтримки, які дадуть можливість нарощувати об'єми агропромислової діяльності та забезпечувати надходження до державного бюджету додаткових грошових ресурсів на визначеному рівні.

Висновки. За результатами дослідження встановлено, що зменшення податку на додану вартість зумовлює значне зростання розміру виробництва та продажу агропромислової продукції, 
фінансових результатів до оподаткування, чистого прибутку. У свою чергу сплата до Державного бюджету України податку на прибуток і податку на додану вартість внаслідок розширення масштабів діяльності агропромислового комплексу збільшиться невеликою мірою. Це пов'язано 3 тим, що частина сільгоспвиробників користується спрощеною системою оподаткування, при котрій податок на прибуток не сплачується до Державного бюджету України, а інша частина сільськогосподарських підприємств до 2017 року користувалася спеціальним режимом оподаткування податком на додану вартість, котрому даний податковий платіж не справлявся до Державного бюджету України. Відповідно до того, держава буде нести видатки на такий вид податкової підтримки агропромислового сектору економіки України. Для того, щоб покрити видатки і отримати доходи держава має здійснювати податкову підтримку за умови залучення одержувачами певного розміру капітальних інвестицій. Для цього розмір зниження податку на додану вартість має бути не більше $16,67 \%$ валових капітальних інвестицій.

Перспективами подальших досліджень $є$ визначення впливу податку на додану вартість на фінансові показники роботи агропромислових компаній з врахуванням наступних періодів їх діяльності з метою отримання більш актуальних і точних даних для подальшого аналізу.

\section{References:}

1. Elektronne skhovyshche Umanskoho natsionalnoho universytetu sadivnytstva (2020) [Digital repository of Uman National University of Horticulture (2020)]. Metodychni pidkhody do vyznachennia rivnia derzhavnoi pidtrymky ahrarnoho sektoru [Methodical approaches to determining level of state support of agrarian sector] <http://lib.udau.edu.ua/bitstream/123456789/4629/1/Методичні\%20підходи\%20до\%20визначення\%20рівня\%2 0державної\%20підтримки\%20аграрного\%20сектору.pdf> (2020, November, 22). [in Ukrainian].

2. Shalimova, N. S. (2017). Otsinka obsiahiv derzhavnoi pidtrymky silskohospodarskykh tovarovyrobnykiv ta urakhuvannia priorytetiv rehionalnoho rozvytku pry yii otrymanni [The estimation of the amounts of state support of agricultural commodity producers and to take into account priorities of regional development at presence it getting]. Scientific Journal «ScienceRise» [Scientific Journal «ScienceRise»], 5/2 (34), 12-17

<http://journals.uran.ua/sciencerise/article/view/102514/98192> (2020, November, 24). [in Ukrainian].

3. Derzhavna sluzhba statystyky Ukrainy [State Statistics Service of Ukraine] (2014). Vyrobnytstvo ta rozpodil valovoho vnutrishnoho produktu za vydamy ekonomichnoi diialnosti za 2001-2013 [Producing and distribution of gross domestic product per kinds of economic activity per 2001-2013].

<http://ukrstat.gov.ua/operativ/operativ2008/vvp/vvp_ric/vtr_kr_u.htm> (2020, November, 16). [in Ukrainian].

4. Halaiko, A. M. (2019). Otsinka vplyvu biudzhetnoi pidtrymky ahropromyslovoho kompleksu na finansovi pokaznyky diialnosti yoho subiektiv hospodariuvannia [The estimation of the influence of budget support of agro-industrial complex on financial indicators of activity its economic entities]. Ekonomika ta derzhava. [Ekonomika ta derzhava], 9, 115-122. <http://www.economy.in.ua/?op=1\&z=4408\&i=18> (2020, November, 25). [in Ukrainian].

5. Halaiko, A. M. (2019). Otsinka vplyvu valovykh kapitalnykh investytsii v ahropromyslovomu kompleksi na obsiah vyrobnytstva yoho subiektiv pidpryiemnytstva [The estimation of the influence of gross capital investment in agro-industrial complex on the amount of producing its entrepreneurship entities]. Suchasni pidkhody do efektyvnoho vykorystannia potentsialu ekonomiky: zbirnyk materialiv III Mizhnarodnoi naukovo-praktychnoi konferentsii (m. Zaporizhzhia, 19 zhovtnia 2019) [Modern of approaches to effective using potential of economics: the collection of materials of the 3rd International Scientific and Practical Conference (Zaporizhzhia, October 19, 2019)], 9-11. [in Ukrainian].

6. Minfin (2021). Indeks infliatsii v Ukraini 2020 [Inflation index in Ukraine 2020]. <https://index.minfin.com.ua/ua/economy/index/inflation/> (2020, November, 17). [in Ukrainian].

7. Kuznietsova, M. (2019). Diialnist subiektiv hospodariuvannia [The activity of economic entities]. Statystychnyi zbirnyk (m. Kyiv, 2019) [Statistical collection (Kyiv, 2019)]. [in Ukrainian].

8. Agropolit.com (2019). Struktura splachenykh podatkiv ahrosektorom za 2017-2018 roky: za vydamy ta sferamy diialnosti [The structure of paid taxes with agricultural sector per 2017-2018: per kinds and spheres of activity]. <https://agropolit.com/infographics/view/91> (2020, November, 18). [in Ukrainian].

9. Halaiko, A. M. (2020). Perspektyvy otrymannia derzhavoiu dodatkovykh dokhodiv v ahropromyslovomu kompleksi. [The prospects of getting by state additional revenues in agro-industrial complex]. Innovatyka $v$ suchasnii osviti ta nautsi: teoriia, metodolohiia, praktyka: materialy III Mizhnarodnoho litnoho naukovoho sympoziumu (m. Odesa, 24-25 lypnia 2020) [Innovation in modern education and science: theory, methodology, practice: 3rd International Summer Scientific Symposium (Odesa, July 24-25, 2020)], 54-58. [in Ukrainian]. 